\title{
ANALISIS FAKTOR FAKTOR YANG MEMPENGARUHI PRODUKSI TEMPE DI KELURAHAN RAJAWALI DI KOTA JAMBI
}

\section{ANALYSIS OF FACTORS AFFECTING TEMPE PRODUCTION IN RAJAWALI REGENCY JAMBI CITY}

\author{
Mohd Sopuwan $^{1)}$, Dompak Napitupulu ${ }^{2)}$ dan Elwamendri ${ }^{2)}$ \\ 1) Alumni Program Studi Agribisnis Fakultas Pertanian Universitas Jambi \\ 2) Dosen Program Studi Fakultas Pertanian Universitas Jambi \\ E-mail:puan_star@yahoo.co.id
}

\begin{abstract}
This research aims to indentify some factors that affected tempe production in Rajawali regency Jambi city. The variable measured in this research is the ammount of soybean, ferment, labor, and volume print tool. This research used primer data that collected from tempe producer through direct interviewing and using some questions that has been prepared before. In this research, all population (38 unit) is taken as respondent. To analyze the effect of independent variable into dependent variable is done by using linear regress model in classical assumption andstatistical tests includetesting $R^{2}$, F-test, and t-test. Based on a classic assumption test not found problem on Multikollinieritas, Autocorrelation, Normality, and Heteroskesdastisitas. The results showedthat the value of a variableamount of soybeans $\left(X_{1}\right)$, ferment $\left(X_{2}\right)$ labor $\left(X_{3}\right)$ and volume print tool, simultaneouslyaffectsproduction oftempeinthe village of Eagle 83,5 percent.Variable number of partially soybeans $\left(X_{1}\right)$, ferment $\left(X_{2}\right)$, Labor $\left(X_{3}\right)$ gif a real effect but print tool volume $(X 4)$ dasnot gif a real effec twith the level of trust of $0.05(\alpha=5 \%)$
\end{abstract}

Keyword : Factor Production, Production, Soybean

\begin{abstract}
ABSTRAK
Penelitian ini bertujuan untuk mengidentifikasi faktor-faktor yang mempengaruhi produksi tempe di Kelurahan Rajawali Kota Jambi. Variabel yang diamati dalam penelitian ini adalah jumlah kedelai, ragi, curahan tenaga kerja, dan volume alat cetak. Penelitian ini menggunakan data primer, diperoleh dari pengrajin tempe melalui wawancara langsung dengan menggunakan daftar pertanyaan yang telah dipersiapkan terlebih dahulu. Pengrajin tempe responden ditentukan secara sensus sebanyak 38 orang. Untuk menganalisis pengaruh variabel bebas terhadap variabel independent pada agroindustri tempe digunakan model regresi linier berganda yaitu asumsi klasik dan uji statistik meliputi uji $R^{2}$, uji $F$ dan uji $t$. Berdasarkan uji asumsi klasik tidak ditemukan masalah pada Multikollinieritas, Autokorelasi, Heteroskesdastisitas, dan Normalitas. Dari hasil penelitian menunjukkan bahwa nilai variabel jumlah kedelai $\left(X_{1}\right)$, ragi $\left(X_{2}\right)$,curahan tenaga kerja $\left(X_{3}\right)$ dan volume alat cetak $\left(X_{4}\right)$, secara bersama-sama mempengaruhi produksi tempe di Kelurahan Rajawali sebesar 83,8 persen. Secara parsial variabel jumlah kedelai $\left(X_{1}\right)$, ragi $\left(X_{2}\right)$,curahan tenaga kerja $\left(X_{3}\right)$ berpengaruh nyata sedangkan volume alat cetak $\left(\mathrm{X}_{4}\right)$ tidak berpengaruh secara nyata dengan tingkat kepercayaan $0,05(\alpha=5 \%)$.
\end{abstract}

Kata Kunci : Faktor Produksi, Produksi, Kedelai 


\section{PENDAHULUAN}

Sektor pertanian yang tangguh merupakan landasan yang kuat bagi terciptanya industrialisasi melalui agribisnis skala kecil. Hal ini menyebabkan agroindustri khususnya agroindustri skala kecil perlu dikembangkan guna mampu meningkatkan pendapatan pelaku agribisnis menyerap banyak tenaga kerja, meningkatkan perolehan devisa melalui peningkatan ekspor dan memunculkan industri baru. Karena keunggulan agroindustri inilah maka agroindustri dapat di pakai salah satu pendekatan pembangunan bagi suatu negara yang berbasis agraris (Soekartawi, 2000).Agroindustri tempe merupakan industri rumah tangga yang dapat memberikan kesempatan berusaha yang lebih luas untuk kelompok masyarakat berpendapatan menengah ke bawah. Agroindustri tempe merupakan industri kecil pangan yang prospektif dan potensial untuk dikembangkan di Propinsi Jambi. Hal ini dikarenakan tempe merupakan produk agroindustri yang memiliki tempat dihati masyarakat, baik sebagai menu pelengkap makanan pokok juga dapat dinikmati sebagai makanan ringan. Tempe memiliki pasar yang prospektif karena masyarakat semakin menyadari bahwa tempe adalah pangan yang bergizi dan sehat.Perkembangan agroindustri tempe di Kota Jambi pada tahun 2009-2012 terjadi peningkatan jumlah unit usaha yaitu sebesar $17,14 \%$. Peningkatan jumlah unit usaha agroindustri ini mengakibatkan jumlah tenaga kerja dan kapasitas produksi ikut meningkat yaitu $18,93 \%$ dan $18,1 \%$. Peningkatan ini menunjukkan usaha agroindustri tempe masih memiliki potensi yang baik untuk diusahakan.

Di Kota Jambi sentra agroindustri tempe terdapat di Kelurahan Rajawali. Hal ini terlihat dari banyak nya unit usaha agroindustri tempe yang beroperasi di kelurahan Rajawali ini. Di kelurahan Rajawali dengan jumlah unit usaha agroindustri tempe sebanyak 38 unit, tingkat penggunaan tenaga kerja nya yaitu sebanyak 121 orang. Jumlah tenaga kerja di kelurahan Rajawali sekitar $49,39 \%$ dari total tenaga kerja pada unit usaha agroindustri tempe. Bahan baku merupakan faktor produksi penting dan perlu diperhatikan, karena tanpa adanya bahan baku maka tidak dapat dihasilkan. Kedelei sebagai bahan baku pembuatan tempe di Kota Jambi pada umumnya berasal dari impor beberapa negara yang dipasok dari Jakarta. Kedelei impor lebih disukai pengrajin dengan pertimbangan kualitas yang lebih bagus dibandingkan dengan kedelei lokal. Dari data sekunder diperoleh bahwa harga bahan baku dari tahun 20042012 terus meningkat dari Rp 2.600/Kg hingga mencapai Rp 7.800/Kg pada tahun 2012.

Harga bahan baku kedelai yang semakin meningkat mengakibatkan pengusaha agroindustri tempe meningkatkan harga penjualan tempe agar pengusaha agroindustri tempe tidak mengalami kerugian. Harga penjualan tempe yang meningkat mangakibatkan permintaan tempe menurun sehingga tempe yang telah diproduksi bersisa. Hal ini dapat mengakibatkan pengrajin tempe mengalami kerugian karena sifat tempe yang tidak tahan lama dan mudah rusak.Selain harga bahan baku kedelai, dalam kegiatan produksi perusahaan tenaga kerja juga merupakan salah satu faktor produksi yang sangat mempengaruhi jalannya suatu usaha termasuk agroindustri tempe. Tenaga kerja yang terlibat pada agroindustri tempe pada umumnya pria yang berasal dari dalam keluarga serta memiliki tingkat pendidikan yang rendah. Modal merupakan salah satu faktor yang mempengaruhi produksi tempe. Modal dalam agroindustri tempe yaitu berupa biaya tetap dan biaya tidak tetap yang digunakan pengrajin dalam produksi tempe. Pengrajin tempe sabagian besar modal usaha yang cukup besar, hal ini terlihat dengan banyaknya sarana produksi yang digunakan.

Penelitian ini berusaha menjawab masalah di atas dengan tujuan untuk melihat gambaran kegiatan agroindustri tempe di Kelurahan Rajawali Kota Jambiserta menganalisis faktor yang mempengaruhi produksi tempe di Kelurahan Rajawali Kota Jambi. 


\section{METODE PENELITIAN}

Penelitian ini dilakukan di Kelurahan Rajawali Kota Jambi, dengan pertimbangan bahwa di Kelurahan Rajawali merupakan salah satu daerah yang mengusahakan produksi tempe terbesar di Kota Jambi.Penentuan Kelurahan Rajawali diambil sebagai sampel karena memiliki pengrajin tempe terbanyak di Kota Jambi.Jumlah pengrajin sampel ditentukan dengan cara sensus sebanyak 38 pengrajin.Penelitian ini dilaksanakan dari tanggal 2 Oktober 2014 sampai tanggal 5 November 2014.Ruang lingkup penelitian difokuskan untuk mengetahui gambaran kegiatan agroindustri tempe serta faktor yang mempengaruhi produksi tempe di Kelurahan Rajawali.

Data yang dikumpulkan dalam penelitian adalah sesuai dengan variabel penelitian.Pengumpulannya dilakukan dengan pengisian kulsioner dari petani responden.Selain itu juga dilakukan pengumpulan data melalui penulusuran internet, khususnya data dari Dinas Perindustrian dan Perdagangan.

Data yang dikumpulkan dari hasil penelitian diolah secara tabulasi, kemudian dianalisis secara kuantitatif dalam bentuk tabel-tabel. Untuk mengetahui faktor-faktor yang mempengaruhi produksi tempe di Kelurahan Rajawali digunakan model fungsi produksi regresi linier berganda (multiple regression). Model regresi linier berganda yaitu :

$$
\begin{aligned}
& Y=\alpha+\beta_{1} X_{1}+\beta_{2} X_{2}+\beta_{3} X_{3}+e \\
& \text { Dimana: } X 1=\text { Jumlah Kedelai }(\mathrm{Kg}) \\
& \mathrm{X} 2 \text { = Ragi (Gr) } \\
& \mathrm{X} 3 \text { = Tenaga Kerja (HOK) } \\
& \mathrm{X} 4=\text { Volume Alat Cetak }\left(\mathrm{Cm}^{3}\right) \\
& B i=\text { Koefisien regresi masing-masing faktor produksi } \\
& \alpha=\text { Intersep (konstanta) }
\end{aligned}
$$

Setelah mengestimasi parameter dengan metode OLS (ordinary least square), langkah selanjutnya yang dilakukan adalah melakukan pengujian terhadap parameter tersebut. Pengujian yang dilakukan meliputi pengujian statistic dan ekonometrik (Koutsoyiannis, 1977). Kriteria statistic dilakukan untuk mengetahui apakah variable independen atau bebas berpengaruh secara nyata atau tidak terhadap variable dependennya atau tak bebas.

Uji F digunakan untuk melihat pengaruh bersama-sama antara variable independen dengan variable dependen secara keseluruhan. Uji statistik yang digunakan :

$\mathrm{F}_{\text {hit }}=\frac{\mathrm{R}^{2} / k}{\left(1-\mathrm{R}^{2}\right) /(n-k-1)} \quad$ atau $\quad \mathrm{F}_{\text {hit }}=\frac{\mathrm{JKR} / k}{\mathrm{JKG} /(n-k-1)}$

Dimana: $\quad R^{2}=$ Koefisien Determinasi Berganda

$$
\begin{aligned}
\mathrm{JKR} & =\text { Jumlah Kuadrat Regresi } \\
\mathrm{JKG} & =\text { Jumlah Kuadrat Galat } \\
\mathrm{k} & =\text { Jumlah Variabel Bebas } \\
\mathrm{n} & =\text { Jumlah Sampel }
\end{aligned}
$$

Kaidah Pengujian :

Jika $F_{\text {hitung }} \leq F_{\text {tabel }}(d f=k ; n-k-1)$ artinya tidak berpengaruh : maka terima $\mathrm{H}_{0}$ atau tolak $\mathrm{H}_{1}$ Jika $F_{\text {hitung }} \geq F_{\text {tabel }}(d f=k ; n-k-1)$ artinya berpengaruh : maka terima $H_{1}$ atau tolak $H_{0}$

Uji $t$ digunakan untuk menghitung koefisien regresi masing-masing variable independen sehingga dapat diketahui pengaruh nyata variable independen tersebut terhadap variable dependennya. Uji statistik yang digunakan :

$$
t_{\text {hit }}=\frac{b i}{S b i}
$$


Dimana: $\quad b_{i} \quad=$ Koefisien regresi variable ke- ${ }_{i}$

$\mathrm{Sb}_{\mathrm{i}} \quad=$ Standar error perkiraan ke- $b_{\mathrm{i}}$

Kaidah pengujian : $\quad$ Jika $t_{\text {hit }} \leq t_{\text {tabel }}(\alpha / 2 ; n-k-1)$ : maka terima $H_{0}$ atau tolak $H_{1}$ Jika $t_{\text {hit }} \geq t_{\text {tabel }}(\alpha / 2 ; n-k-1)$ : maka terima $H_{1}$ atau tolak $H_{0}$

Dimana: $\quad n=$ jumlah sampel

$\mathrm{k}=$ jumlah variable bebas

Jika hasil pengujian menolak $\mathrm{H}_{0}$ maka koefisien $b_{i}$ duga tidak sama dengan nol dan variabel yang diuji mempunyai pengaruh yang nyata terhadap variable dependen nyata atau dengan kata lain $b_{i}$ dugaan signifikan secara statistik. Sebaliknya, jika hasil pengujian menerima $\mathrm{H}_{0}$ maka koefisien dugaan sama dengan nol dan variabel yang diuji tidak memiliki pengaruh nyata terhadap variable dependennya.

\section{HASIL DAN PEMBAHASAN}

\section{Gambaran umum responden}

Identitas petani merupakan ciri yang melekat pada petani, ciri-ciri tersebut akan menggambarkan potensi petani, potensi yang dimiliki petani akan mempengaruhi dia dalam mengambil suatu keputusan terhadap apa yang akan dikerjakan dalam keberhasilan usahataninya. Adapun identitas pengrajin tempe dalam penelitian ini meliputi umur, tingkat pendidikan terakhir, jumlah anggota keluarga, dan pengalaman berusaha agroindustri tempe.

Umumnya usia akan mempengaruhi produktivitas kerja dan kemampuan berpikir, bertindak dan mencoba, dimana seseorang yang lebih muda biasanya akan lebih terbuka serta mudah mengadopsi suatu inovasi baru yang diberikan. Sedangkan Pengrajin yang termasuk golongan tua tentunya memiliki pengalaman berusaha lebih banyak sehingga akan semakin hati-hati dalam mengambil keputusan. Soekartawi (2002) menyatakan bahwa semakin muda petani biasanya mempunyai semangat untuk lebih tahu apa yang belum mereka ketahui, sehingga dengan demikian petani berusaha untuk lebih cepat mengadopsi inovasi baru, walaupun kadang-kadang kurang berpengalaman dalam mengadopsi inovasi tersebut. Usia produktif biasanya berada pada jenjang 15-54 tahun. Dalam penelitian ini umur sampel yang termuda adalah 21 tahun dan yang tertua adalah 68 tahun. Mayoritas pengrajin tempe di Kelurahan Rajawali yang menjadi responden dalam penelitian ini adalah petani dalam usia produktif yaitu 35-39 tahun (42,10\%). Pengrajin muda sehat mempunyai kemampuan fisik untuk bekerja daripada pengrajin tua, pengrajin muda umumnya juga lebih cepat menerima hal baru daripada pengrajin yang sudah berusia lanjut, karena mereka lebih berani menanggung resiko.

Pendidikan umumnya mempengaruhi cara berpikir pengrajin. Pendidikan yang tinggi dengan umur yang relatif masih muda akan menyebabkan pengrajin lebih dinamis. Pendidikan dapat diperoleh dari sumber informal, misalnya dari kursus-kursus atau penyuluhan, selain pendidikan formal. Tingkat pendidikan pengrajin juga sangat berhubungan dengan kesediaan mencoba atau menerima sesuatu yang baru. Menurut Hernanto (1998), bahwa keterbatasan tingkat pendidikan akan mempengaruhi cara berfikir, menerima, ataupun menolak hal-hal baru. Tingkat pendidikan yang rendah menyebabkan petani kurang bijaksana dalam mengambil keputusan maupun dalam menyerap teknologi dan begitu juga sebaliknya. Dalam penelitian ini, tingkat pendidikan petani diukur berdasarkan pendidikan formal yang pernah dilalui pengrajin. Berdasarkan pada tingkat pendidikan formal, sebagian besar responden menempuh pendidikan setara sekolah dasar (SD) (7,90\%), sekolah lanjutan tingkat pertama (SLTP/MTS) (52,63\%) dan sekolah menengah umum (SMU) (39,47\%).Jenjang pendidikan formal yang ditempuh pengrajin tempe relatif terbatas sehingga usaha yang dijalankan secara 
sederhana sesuai dengan kebiasaan yang selama ini dilakukan dan informasi yang didapatkan antar pengrajin.

Pengalaman berusaha agroindustri tempe merupakan lama waktu yang telah dijalani pengrajin tempe dalam menjalankan kegiatan usahanya. Menurut Akib (2011), pengalaman dapat menjadi acuan dalam penyusunan langkah dimasa yang akan datang. Penentuan alternatif yang memungkinkan merupakan langkah awal dalam pencapaian tujuan berusaha agroindustri tempe. Semakin lama bekerja sebagai pengrajin tempe, maka semakin berpengalaman sehingga dapat mengurangi resiko dan meningkatkan produksi tempe. Tingkat pengalaman pengrajin tempe di daerah penelitian terbesar adalah antara $1-7,2$ tahun $(36,84$ \%). Hal ini menunjukkan bahwa pengrajin di daerah penelitian pengalamannya di dalam kegiatan berusaha tempe masih rendah. Aspek pengalaman pengrajin juga berpengaruh terhadap keputusan pengrajin untuk mengembangkan usaha tempe. Pengalaman seseorang akan dapat dijadikan tolak ukur untuk pengembangan kegiatan dimasa mendatang, karena jika semakin lama bekerja seseorang diharapkan lebih baik dan sempurna dalam melaksanakan tugasnya.

Jumlah tanggungan keluarga adalah banyaknya anggota keluarga yang terdiri dari; istri, dan anak, serta orang lain yang turut serta dalam keluarga berada atau hidup dalam satu rumah dan makan bersama yang menjadi tanggungan kepala keluarga. Jumlah anggota keluarga yang menjadi tanggungan bagi pengrajin sebagai kepala keluarga akan berpengaruh terhadap motivasi berusaha tempe untuk memenuhi kebutuhan hidup sehari-hari. Berdasarkan kriteria jumlah tanggungan keluarga, sebagian besar pengrajin responden memiliki jumlah tanggungan keluarga $\leq 2$ orang $(76,31 \%)$, sedangkan jumlah tanggungan keluarga sebanyak $\geq 5$ orang (2,63\%) (1 orang). Banyaknya jumlah tanggungan keluarga akan mendorong pengrajin untuk melakukan banyak aktivitas terutama dalam mencari dan menambah pendapatan keluarganya.

\section{Keadaan Kegiatan Agroindustri Tempe}

Kelurahan Rajawali merupakan salah satu kawasan pemasok tempe di Kota Jambi. Usaha pembuatan tempe merupakan mata pencaharian utama pengrajin tempe di Kelurahan Rajawali sejak tahun 1967. Pada umumnya pembuatan tempe di Kelurahan Rajawali dilakukan pada pagi hari sekitar pukul 10.00-15.00 WIB hingga tahap pencucian lalu dilanjutkan dengan tahap perendaman sampai dengan hari berikutnya agar diperoleh kedelai yang lunak sehingga diperlukan waktu merendam selama satu malam. Proses pembuatan tempe menggunakan alat-alat yaitu mesin giling, mesin air, drum, saringan, ember, kere, corong dan baskom.langkah-langkah pembuatan tempe :

1. Biji kedelai dipilih yang bermutu baik, kemudian dicuci dengan air bersih di dalam drum.

2. Biji kedelai direbus selama \pm 30 menit agar dalam proses pengupasan menjadi mudah.

3. Biji kedelai direndam selama satu malam didalam drum agar menjadi lunak dan mencegah pertumbuhan bakteri pembusuk pada saat proses pemeraman.

4. Pengupasan kulit ari dengan menggunakan saringan agar kulit ari terkelupas menjadi keping keping kedelai.

5. Biji kedelai digiling agar kedelai yang dihasilkan menjadi keping kedelai

6. Keping kedelai kemudian di bersihkan dengan air bersih

7. Peragian pada keping kedelai yang telah didinginkan dengan merata agar diperoleh kualitas tempe yang baik.

8. Kedelai yang telah dicampur dengan ragi dibungkus dengan daun dan plastik dan disimpan (diperamkan) selama beberapa hari yaitu 1-2 hari hingga diperoleh "tempe".

\section{Penggunaan Jumlah Kedelai}


Kedelai merupakan bahan baku utama dalam proses pembuatan tempe yang menentukan jumlah tempe yang akan diproduksi. Bahan baku kedelai yang digunakan pengrajin tempe di daerah penelitian adalah kedelai impor. Hal ini karena menurut pengrajin di daerah penelitian kualitas kedelai impor lebih baik dari kedelai lokal. Penggunaan bahan baku kedelai di daerah penelitian rata-rata adalah 109,6 Kg dalam satu kali produksi. Disribusi pengrajin tempe berdasarkan jumlah bahan baku yang digunakan di daerah penelitian dapat dilihat pada Tabel 1 berikut.

Tabel. 1 Distribusi Pengrajin Responden Berdasarkan Jumlah Kedelai di Daerah Peneliian Tahun 2014

\begin{tabular}{ccc}
\hline Jumlah Kedelai & Frekuensi (Orang) & Persentase (\%) \\
\hline $45-60$ & 3 & 7,90 \\
$61-75$ & 0 & 0 \\
$76-90$ & 8 & 21,05 \\
$91-105$ & 10 & 26,32 \\
$106-120$ & 5 & 13,16 \\
$121-135$ & 3 & 7,89 \\
$136-150$ & 9 & 23,68 \\
\hline Jumlah & 38 & 100 \\
\hline
\end{tabular}

Berdasarkan Tabel 1, jumlah bahan baku kedelai terbesar yang digunakan pengrajin di daerah penelitian yaitu antara 91-105 Kg/hari. Penggunaan bahan baku kedelai terbesar yang digunakan pengrajin tempe yaitu $150 \mathrm{Kg}$ satu kali produksi, sedangkan penggunaan bahan baku kedelai terkecil yang digunakan pengrajin tempe yaitu $45 \mathrm{Kg}$ dalam satu kali produksi.Usaha agroindustri tempe sangat bergantung pada bahan baku kedelai. Ketersediaan jumlah kedelai dan harga kedelai menjadi faktor yang mempengaruhi harga tempe. Jika pasokan jumlah kedelai sedikit, maka pengrajin tidak dapat memproduksi kedelai dengan jumlah yang banyak, sehingga harga tempe akan naik. Selain itu, harga kedelai juga mempengaruhi harga tempe. Harga bahan baku kedelai yang semakin meningkat membuat pengrajin menaikkan harga tempe.

Ragi

Ragi Tempe merupakan salah satu bahan baku yang digunakan dalam proses pembuatan tempe. Bahan baku ragi berguna untuk proses fragmentasi pada kedelai sehingga menjadi tempe. Penggunaan bahan baku ragi tempe di daerah penelitian rata-rata adalah 349,474 gr dalam satu kali produksi. Disribusi pengrajin tempe berdasarkan jumlah ragi tempe yang digunakan di daerah penelitian dapat dilihat pada Tabel 2.

Tabel. 2 Distribusi Pengrajin Responden Berdasarkan Jumlah Ragi Tempe di Daerah Penelitian Tahun 2014

\begin{tabular}{ccc}
\hline Biaya Penyusutan & Frekuensi (Orang) & Persentase (\%) \\
\hline $290-312,86$ & 5 & 13,16 \\
$312,87-335,72$ & 11 & 28,95 \\
$335,73-358,58$ & 11 & 28,95 \\
$358,59-381,44$ & 2 & 5,26 \\
$381,44-404,30$ & 5 & 13,16 \\
$404,31-427,16$ & 3 & 7,89 \\
$427,17-450,02$ & 1 & 2,63 \\
\hline Jumlah & 38 & 100
\end{tabular}


Berdasarkan Tabel 2 menunjukkan bahwa jumlah ragi tempe terbesar yang digunakan pengrajin di daerah penelitian yaitu antara $312,87-335,72 \mathrm{gr}$ dan $335,73-358,58$ gr dalam satu kali produksi. Penggunaan ragi tempe terbesar yang digunakan pengrajin tempe yaitu 450 gr dalam satu kali produksi, sedangkan penggunaan ragi tempe terkecil yang digunakan pengrajin tempe yaitu $290 \mathrm{gr}$ dalam satu kali produksi. Penggunaan ragi tempe sangat menentukan keberhasilan tempe yang dihasilkan.

\section{Tenaga Kerja}

Tenaga kerja pada pengrajin tempe meliputi tenaga kerja yang bersasal dari dalam keluarga dan luar keluarga. Tenaga kerja yang berasal dari dalam keluarga terdiri dari kepala keluarga (suami), istri dan anak serta orang lain yang menjadi tanggungan keluarga pengrajin tersebut. Tenaga kerja luar keluarga umumnya adalah tenaga kerja pria dan wanita yang dibayar. Menurut Rahim dan Hastuti (2007), curahan tenaga kerja adalah besarnya tenaga kerja efektif yang dipakai. Ukuran tenaga kerja dapat dinyatakan dalam hari orang kerja (HOK) atau hari kerja orang (HKO). Menurut Suratiyah (2009), ada beberapa hal yang membedakan antara tenaga kerja luar keluarga dan dan tenaga luar antara lain adalah komposisi menurut umur, jenis kelamin kualitas dan kegiatan kerja (prestasi kerja). Kegiatan kerja tenaga luar sangat dipengaruhi sistem upah, lamanya waktu kerja, kehidupan sehari-hari, kecakapan dan umur tenaga kerja.

Tabel 3. Distribusi Frekuensi Petani Berdasarkan Tenaga Kerja di Daerah Penelitian

\begin{tabular}{ccc}
\hline Tenaga Kerja (HOK) & Frekuensi (Orang) & Persentase (\%) \\
\hline $1,06-1,27$ & 4 & 10,53 \\
$1,28-1,49$ & 8 & 21,05 \\
$1,50-1,71$ & 10 & 26,31 \\
$1,72-1,93$ & 6 & 15,79 \\
$1,94-2,15$ & 4 & 10,53 \\
$2,15-2,37$ & 4 & 10,53 \\
$2,38-2,59$ & 2 & 5,26 \\
\hline Jumlah & 38 & 100 \\
\hline
\end{tabular}

Berdasarkan Tabel 3menunjukkan, penggunaan tenaga kerja rentang antara 1,50 1,71 HOK dalam satu kali produksi merupakan paling tinggi dengan 26,31 persen (10 orang). Penggunaan tenaga kerja pengrajin tempe responden terbesar dalam satu kali produksi yaitu 2,50 HOK dan biaya terkecil yaitu 1,06 HOK. Rata-rata penggunaan tenaga kerja dalam usaha agroindustri tempe dalam satu kali produksi yaitu 1,73 HOK. Di daerah penelitian, penggunaan tenaga kerja porsi terbesar dilakukan oleh tenaga kerja dalam keluarga yang terdiri atas suami dan istri dengan jumlah keseluruhan yaitu 53,38 HOK dalam satu kali produksi dan rata-rata per pengrajin yaitu 1,4, HOK dalam satu kali produksi. Sedangkan jumlah tenaga kerja luar keluarga di daerah penlitian yaitu $12,46 \mathrm{HOK}$ dalam satu kali produksi dengan rata-rata per petani yaitu $0,33 \mathrm{HOK}$ dalam satu kali produksi. Kegiatan agroindustri tempe terdiri dari perebusan, penggilingan dan fermentasi, pencetakan, pemotongan dan pemasaran. Penggunaan tenaga kerja sebagian besar dilakukan oleh tenaga kerja pria (suami), sedangkan tenaga kerja wanita (istri) sebagian besar berperan pada proses pencetakan dan pemotongan.

\section{Volume Alat Cetak}

Volume alat cetak merupakan ukuran alat cetak yang digunakan pengrajin untuk memproduksi tempe. Alat cetak tempe ini terbuat dari kayu berbentuk petak panjang. Volume alat cetak tempe yang digunakan pengrajin berbeda-beda. Volume alat cetak tempe di daerah penelitian rata-rata adalah $3548,38 \mathrm{~cm}^{3}$ dalam satu kali produksi. Disribusi pengrajin tempe 
berdasarkan volume alat cetak yang digunakan di daerah penelitian dapat dilihat pada Tabel 4 berikut.

Tabel. 4 Distribusi Pengrajin Responden Berdasarkan Volume Alat Cetak Tempe di Daerah Peneliian Tahun 2014

\begin{tabular}{ccc}
\hline Volume Alat Cetak Tempe & Frekuensi (Orang) & Persentase (\%) \\
\hline $3277,12-3372,01$ & 18 & 47,37 \\
$3372,02-3466,90$ & 0 & 0 \\
$3466,91-3561,79$ & 0 & 0 \\
$3561,80-3656,68$ & 9 & 23,68 \\
$3656,69-3751,57$ & 0 & 0 \\
$3751,58-3846,46$ & 1 & 2,63 \\
$3846,47-3941,35$ & 10 & 26,32 \\
\hline Jumlah & 38 & 100
\end{tabular}

Berdasarkan Tabel 4, Volume Alat Cetak Tempe terbesar yang digunakan pengrajin di daerah penelitian yaitu antara $3277,12-3372,01 \mathrm{~cm}^{3}$ dalam satu kali produksi. Penggunaan volume alat cetak tempe terbesar yang digunakan pengrajin tempe yaitu $3941,28 \mathrm{~cm}^{3}$ dalam satu kali produksi, sedangkan penggunaan volume alat cetak tempe terkecil yang digunakan pengrajin tempe yaitu $3277,12 \mathrm{~cm}^{3}$ dalam satu kali produksi. Volume alat cetak tempe digunakan sebagai media untuk membentuk tempe yang diproduksi. Besar kecilnya tempe yang dijual pengrajin tergantung dari besar kecilnya alat cetak yang digunakan.Alat cetak tempe mempengaruhi besar kecilnya tempe yang dihasilkan. Hal ini dapat menarik minat konsumen untuk membelinya dengan harga yang sama dengan alat cetak yang lebih kecil, sehingga dapat meningkatkan penjualan pengrajin. Penjualan yang meningkat akan memberikan peluang pengrajin untuk meningkatkan produksi tempenya. Akan tetapi jika pengrajin tidak dapat menetapkan harga yang sesuai, maka pengrajin dapat mengalami kerugian.

\section{Produksi Tempe}

Menurut Mubyarto (1991), besarnya produksi akan menentukan besarnya kesempatan ekonomi yang diterima. Apabila tingkat produksi yang diperoleh petani tinggi, maka arus kesempatan ekonomi yang akan diperoleh cukup besar dan sebaliknya. Tingkat produksi yang tinggi akan memberikan pendapatan yang tinggi juga. Hasil penelitian menunjukkan bahwa rata-rata produksi yang diperoleh pengrajin tempe yaitu sebanyak $233,28 \mathrm{~kg}$ dalam satu kali produksi. Adapun distribusi pengrajin tempe berdasarkan tingkat produksi tempe dapat dilihat pada Tabel 4 berikut.

Tabel 5. Distribusi Pengrajin Tempe Berdasarkan Jumlah Produksi Di Daerah Penelitian Tahun 2014

\begin{tabular}{ccc}
\hline Produksi Tempe & Frekuensi (Orang) & Persentase (\%) \\
\hline $140-16-168,48$ & 3 & 7,90 \\
$168,49-196,81$ & 8 & 21,05 \\
$196,81-225,14$ & 13 & 34,21 \\
$196,15-253,47$ & 1 & 2,63 \\
$253,48-281,79$ & 1 & 2,63
\end{tabular}




\begin{tabular}{ccc}
$281,80-310,12$ & 9 & 23,68 \\
$310,13-338,44$ & 3 & 7,90 \\
\hline Jumlah & 38 & 100 \\
\hline
\end{tabular}

Berdasarkan Tabel 4 distribusi produksi yang terbanyak untuk pengrajin tempe yaitu antara 196,81-225,14 kg dalam satu kali produksi yaitu sebanyak 13 responden atau 34,21 \%. Produksi tempe pengrajin di daerah penelitian tertinggi yaitu $338,40 \mathrm{~kg} /$ dalam satu kali produksi, sedangkan produksi tempe pengrajin di daerah penelitian terendah yaitu 140,16kg dalam satu kali produksi.Tempe yang diproduksi pengrajin di daerah penelitian terdiri dari 6 jenis tempe yaitu tempe daun kotak, tempe daun bulat besar, tempe daun bulat kecil, tempe plastik bulat besar, tempe plastic gepeng besar dan tempe plasik gepeng kecil. Sebagian besar pengrajin di daerah penelitian membuat tempe daun, baik yang besar maupun yang kecil. Upaya sebagian pengrajin dalam meningkatkan produksi tempe yaitu dengan memasukkan bahan baku kedelai beserta ampasnya. Hal ini dapat meningkatkan produksi tempe, akan tetapi kualitas tempe akan menjadi buruk. Selain itu harga tempe ini juga akan turun.

\section{Faktor-faktor yang Mempengaruhi Produksi Tempe di Kelurahan Rajawali}

Pengujian model persamaan dengan metode regresi linier berganda untuk faktorfaktor yang mempengaruhi produksi tempe diharapkan memenuhi bebas untuk semua asumsi yang diisyaratkan, diantaranya adalah asumsi multikolinieritas, autokorelasi, heteroskedastisitas dan normalitas. Dengan terpenuhinya asumsi-asumsi tersebut, maka akan menghasilkan variabel penduga terbaik yang tidak bias atau disebut BLUE (Best Linear Unbiased Estimator). Sebaliknya, jika terdapat salah satu asumsi dalam model regresi linier berganda yang tidak dapat dipenuhi oleh fungsi yang diperoleh, maka kebenaran pendugaan model atau pengujian hipotesis untuk pengembalian keputusan menjadi diragukan.

Pengujian ini bertujuan untuk mengetahui apakah tiap-tiap variabel independen saling berhubungan secara linear, apabila sebagian atau seluruh variabel independen berkorelasi kuat berarti terjadi multikolineritas (Gujarati, 2006).Setelah dilakukan uji multikolineritas pada variabel-variabel independen dengan pengukuran terhadap VIF hasilnya menunjukkan bahwa semua variabel independen pada model yang diajukan bebas dari multikolinearitas atau tidak ada multikolinearitas antar variabel independen dalam model. Hal ini ditunjukkan dengan nilai VIF yang berada di bawah 10 dan nilai tolerence lebih dari 0,1. Jadi, dapat disimpulkan bahwa variabel independen bebas dari masalah multikolinieritas.

Berdasarkan hasil pengujian data yang telah dilakukan terlihat dalam pengujian nilai Durbin-Watson (DW) yaitu sebesar 1,917. Maka hasil yang diperoleh berada dalam dua kuadran yaitu $-2<1,917<2$ dan oleh sebab itu dapat disimpulkan di dalam data penelitian ini tidak ditemukan gejala autokorelasi yang serius baik yang bernilai positif maupun negatif. Berdasarkan hasil analisis diketahui bahwa nilai korelasi ketiga variabel independen dengan Unstandardized Residual memiliki nilai signifikansi lebih dari 0,05, sehingga dapat disimpulkan bahwa tidak terjadi masalah heteroskedastisitas pada model regresi.

Untuk mengetahui masalah normalitas dapat ditunjukkan oleh hasil pengujian Kolmogorov Smirnov. Dengan taraf nyata 5 persen diperoleh nilai tau sig. sebesar 0,489, yang berarti nilai tersebut lebih besar dari 5 persen atau 0,05 hal ini menunjukkan tidak signifikan. Tidak signifikan berarti data relatif sama dengan rata-rata sehingga disebut normal, dengan kata lain asumsi normalitas telah terpenuhi.

\section{Analisis Faktor-faktor yang Mempengaruhi Produksi Tempe di Kelurahan Rajawali}

Setelah dilakukan pengujian penyimpangan asumsi klasik yang menunjukkan bahwa tidak terdapat gejala multikolinearitas, heteroskedastisitas, autokorelasi dan normalitas. Hal ini menunjukkan juga bahwa model analisis regresi linier berganda yang dipakai relevan untuk 
diteliti. Berdasarkan hasil analisis SPSS 16 dengan metode regresi linier berganda terhadap faktor-faktor yang mempengaruhi produksi tempe di daerah penelitian diperoleh :

Tabel 5. Koefisien Variabel Independent Terhadap Produksi Tempe

\begin{tabular}{llrrrr}
\hline \multirow{2}{*}{ Model } & \multicolumn{2}{c}{ Unstandardized Coefficients } & & \\
\cline { 2 - 3 } Coefficients $^{\mathrm{a}}$ & \multicolumn{1}{c}{ Std. Error } & \multicolumn{1}{c}{ T } & \multicolumn{1}{c}{ Sig. } \\
\hline 1 & (Constant) & -133.367 & 60.948 & -2.188 & .036 \\
& Jumlah Kedelai & .893 & .203 & 4.405 & .000 \\
& Ragi & .213 & .094 & 2.275 & .030 \\
Curahan Tenaga & 61.919 & 16.375 & 3.781 & .001 \\
Kerja & .025 & .014 & 1.766 & .087 \\
Volume Alat Cetak & & &
\end{tabular}

Berdasarkan hasil di atas diperoleh persamaan :

$$
\mathrm{Y}=-133,367+0,893 \times 1+0,213 \times 2+61,919 \times 3+0,025 \times 4+e
$$

Hasil analisis yang diperoleh menunjukkan nilai koefisien determinasi $R^{2}$ (adj.) sebesar 83,8 persen yang menunjukkan bahwa variabel-variabel independen (terdiri dari Jumlah Kedelai (X1), ragi (X2), curahan tenaga kerja (X3),volume alat cetak(X4)) dalam model yang dibangun mampu menjelaskan sebanyak 83,8 persen perubahan yang terjadi pada produksi tempe di daerah penelitian, sedangkan sisanya sebesar 16,2 persen diterangkan oleh faktor lain di luar model.

\section{Pengujian Secara Simultan}

Pengujian secara simultan digunakan untuk melihat bagaimana variabel independen secara bersama-sama atau simultan mempengaruhi variabel dependen. Pengujian ini dilakukan dengan menggunakan uji $F$ pada tingkat kepercayaan 95 persen $(\alpha=0,05)$. Dari pengujian secara simultan diperoleh nilai $F_{\text {hitung }}$ sebesar 49,021 atau lebih besar dari $F_{\text {tabel }}$ yaitu sebesar 2,88 pada tingkat kepercayaan 95 persen ( $\alpha=5$ persen) dan df dengan pembilang $(k-1)=4$ dan penyebut $(n-k)=38-5=33$. Dengan demikian pada model persamaan ini variabel jumlah kedelai, ragi, curahan tenaga kerja,dan volume alat cetak secara bersama-sama berpengaruh secara signifikan terhadap variabel produksi tempe.

\section{Pengujian Secara Parsial}

Penelitian ini dilakukan dengan analisis regresi berganda (multiple regression analysis), dengan memperhatikan nilai $t_{\text {hitung }}$ dari hasil regresi tersebut untuk mengetahui signifikansi variabel independen secara terpisah atau parsial terhadap variabel dependen pada tingkat $\alpha=$ $5 \%$ dengan syarat apabila variabel independen signifikan terhadap variabel dependen maka terdapat pengaruh antara variabel independen terhadap variabel dependen. Sedangkan apabila tidak signifikan maka tidak terdapat pengaruh antara variabel independen terhadap variabel dependen. Pengujian koefisien regresi parsial atau uji $t$ digunakan untuk menguji apakah hipotesis yang diajukan dalam penelitian ini diterima atau ditolak dengan mengetahui apakah variabel independen secara individual mempengaruhi variabel dependen.

\section{Pengaruh Jumlah Kedelai $\left(\mathrm{X}_{1}\right)$ Terhadap Produksi Tempe $(\mathrm{Y})$ di Daerah Penelitian}

Bahan baku utama pembuat tempe yaitu kedelai. Bahan baku kedelai yang digunakan diduga memiliki hubungan yang positif terhadap produksi tempe, jika semakin banyak kedelai yang digunakan maka semakin banyak produksi yang dihasilkan dan begitu juga sebaliknya. 
Tanda estimasi yang dimiliki oleh variabel jumlah kedelai bernilai positif. Hal ini menjelaskan bahwa dengan bertambahnya jumlah kedelai akan meningkatkan produksi tempe. Nilai koefisien jumlah kedelai yaitu sebesar 0,893 , hal ini berarti jika jumlah kedelai bertambah sebesar satu satuan, maka produksi tempe akan meningkat sebesar 0,893 satuan, dengan syarat cateris paribus.Sedangkan berdasarkan hasil penelitian Ayu Mutiara (2010) nilai koefisien kedelainya 0,517. Hal ini dapat dilihat perbandingan nilai koefisien jumlah kedelai 0,893 lebih besar dari 0,517 Ayu Mutiara (2010). Berdasarkan analisis dengan metode regresi linier berganda, didapatkan bahwa nilai Sig. untuk jumlah kedelai $\left(X_{1}\right)$ sebesar 0,000 lebih rendah daripada nilai $\alpha(0,05)$, dan diketahui bahwa $t_{\text {hitung }}>t_{\text {tabel }}(4,405>2,030)$. Hal ini menunjukkan bahwa variabel jumlah kedelai terbukti secara signifikan mempunyai pengaruh yang nyata terhadap produksi tempe di Kelurahan Rajawali dan sesuai dengan hasil penelitian Ayu Mutiara (2010) yaitu bahan baku berpengaruh secara signifikan terhadap produksi tahu dan tempe.

\section{Pengaruh Ragi $\left(\mathrm{X}_{2}\right)$ Terhadap Produksi Tempe (Y) Di Daerah Penelitian}

Variabel Ragi merupakan jumlah ragi yang digunakan dalam proses produksi tempe. Ragi merupakan bahan baku yang penting dalam proses fragmentasi. Variabel ragi diduga memiliki hubungan yang positif terhadap produksi tempe, jika semakin bertambah ragi yang digunakan maka produksi semakin meningkat.Tanda estimasi yang dimiliki oleh variabel ragi bernilai positif. Hal ini menjelaskan bahwa dengan bertambahnya ragi yang digunakan pengrajin tempe akan meningkatkan produksi tempe. Nilai koefisien ragi yaitu sebesar 0,213 , hal ini berarti jika jumlah ragi yang digunakan bertambah sebesar satu satuan, maka produksi tempe akan meningkat sebesar 0,213 satuan, dengan syarat cateris paribus.Sedangkan berdasarkan hasil penelitian Sudarmi (2008) nilai koefisien dalam penelitiannya 0,059 . Hal ini dapat dilihat perbandingan nilai koefisien ragi tempe 0,213 lebih besar dari 0,059 Sudarmi (2008).Berdasarkan analisis dengan metode regresi linier berganda, didapatkan bahwa nilai Sig. untuk Ragi $\left(\mathrm{X}_{2}\right)$ sebesar 0,030 lebih rendah dari pada nilai $\alpha(0,05)$, dan diketahui bahwat $_{\text {hitung }}>t_{\text {tabel }}(2,275>2,030)$. Hal ini menunjukkan bahwa variabel Investasi terbukti secara signifikan mempengaruhi produksi tempe di Kelurahan Rajawali dan sesuai dengan hasil penelitian Sudarmi (2008) yaitu ragi berpengaruh secara signifikan terhadap produksi tempe.

\section{Pengaruh Curahan Tenaga Kerja $\left(X_{3}\right)$ Terhadap Produksi Tempe $(Y)$ di Daerah Penelitian}

Variabel curahan tenaga kerja sangat memegang peranan penting dalam kegiatan produksi tempe ini, dimulai dari pembersihan sampai pemasaran. Variabel curahan tenaga kerja diduga memiliki hubungan positif terhadap produksi tempe, jika semakin banyak curahan tenaga kerja, maka semakin meningkatkan produksi tempe atau sebaliknya. Di daerah penelitian tenaga kerja berupa sebagai pemilik maupun sebagai buruh biasa yang mengelolah hingga memasarkan produksi tempe. Tanda estimasi yang dimiliki oleh variabelcurahan tenaga kerja bernilai positif. Hal ini menjelaskan bahwa dengan bertambahnya curahan tenaga kerja akan meningkatkan produksi tempe. Nilai koefisien tenaga kerja yaitu sebesar 61,919 , hal ini berarti jika curahan tenaga kerja bertambah sebesar satu satuan, maka produksi tempe akan meningkat sebesar 97,671 satuan, dengan syarat cateris paribus.Sedangkan berdasarkan hasil penelitian Ayu Mutiara (2010) nilai koefisien curahan tenaga kerja yaitu 0,234 terhadap produksi tempe. Hal ini dapat dilihat perbandingan nilai koefisien curahan tenaga kerja 61,919 lebih besar dari 0,234 Ayu Mutiara (2010).Berdasarkan analisis dengan metode regresi linier berganda, didapatkan bahwa nilai Sig. untuk curahan tenaga kerja $\left(X_{3}\right)$ sebesar 0,001 , lebih kecil daripada nilai $\alpha(0,05)$, dan diketahui bahwa $t_{\text {hitung }}>t_{\text {tabel }}(3,781>2,030)$. Hal ini menunjukkan bahwa variabel dugaan, yakni curahan tenaga kerja terbukti secara signifikan mempengaruhi secara nyata terhadap produksi tempe di Kelurahan Rajawali. Hasil ini menjelaskan bahwa peningkatan Hari Orang Kerja yang digunakan dalam suatu proses 
produksi tempe secara langsung meningkatkan produksi tempe dan sesuai dengan hasil penelitian Ayu Mutiara (2010) yaitu curahan tenaga kerja berpengaruh secara signifikan terhadap produksi tempe.

\section{Pengaruh Volume Alat Cetak $\left(\mathrm{X}_{4}\right)$ Terhadap Produksi Tempe $(\mathrm{Y})$ Di Daerah Penelitian.}

Variabel volume alat cetak merupakan ukuran media yang digunakan pengrajian dalam proses produksi tempe. Alat cetak merupakan media untuk mencetak atau membentuk tempe. Variabel volume alat cetak diduga memiliki hubungan yang positif terhadap produksi tempe, jika semakin bertambah volume alat cetak yang digunakan maka produksi semakin meningkat. Tanda estimasi yang dimiliki oleh variabel volume alat cetak bernilai positif. Hal ini menjelaskan bahwa dengan bertambahnya volume alat cetak yang digunakan pengrajin tempe akan meningkatkan produksi tempe. Nilai koefisien volume alat cetak yaitu sebesar 0,025 , hal ini berarti jika volume alat cetak bertambah sebesar satu satuan, maka produksi tempe akan meningkat sebesar 0,025 satuan, dengan syarat cateris paribus. Berdasarkan analisis dengan metode regresi linier berganda, didapatkan bahwa nilai Sig. untuk ragi $\left(\mathrm{X}_{2}\right)$ sebesar 0,087 lebih tinggi dari pada nilai $\alpha(0,05)$, dan diketahui bahwa $t_{\text {hitung }}<t_{\text {tabel }}(1,766<2,030)$. Hal ini menunjukkan bahwa variabel volume alat cetak tidak signifikan mempengaruhi produksi tempe di Kelurahan Rajawali.

\section{KESIMPULAN DAN SARAN}

Berdasarkan hasil penelitian terhadap analisis faktor - faktor yang mempengaruhi produksi tempedi Kelurahan Rajawali Kota Jambi dapat disimpulkan bahwa variabel jumlah kedelai, ragi, curahan tenaga kerja, dan volume alat cetak secara bersama-sama mempengaruhi produksi tempe di Kelurahan Rajawali sebesar 83,8 persen. Secara parsial yang berpengaruh secara nyata adalah jumlah kedelai, ragi curahan tenaga kerjasedangkan volume alat cetak tidak berpengaruh secara nyata terhadap faktor produksi di daerah penelitian.

\section{UCAPAN TERIMA KASIH}

Pada kesempatan ini penulis ingin menyampaikan terima kasih kepada Lurah Rajawali, yang memfasilitasi pelaksanaan penelitian di lapangan.

\section{DAFTAR PUSTAKA}

Akib Tuwo, M. 2011. Ilmu Usahatani, Teori dan Aplikasi Menuju Sukses. UNHALU PRESS: Kendari.

Ayu Mutiara . 2010. Analisis pengaruh Bahan Baku, Bahan Bakar dan Tenaga Kerja Terhadap Produksi Tempe di Kota Semarang (Studi Kasus Di Kelurahan Krobokan). Skripsi Universitas Diponegoro. Semarang.

Gujarati, Damodar N. 2006. Dasar-dasar Ekonometrika Edisi Ketiga. Erlangga: Jakarta.

Hernanto, F. 1998. IImu Usahatani. Penebar Swadaya. Jakarta.

Koutsoyiannis A. 1977. Theory of Econometrics. The Macmillan Press LTD. Ontario.

Mubyarto, 1991. Pengantar Ekanomi Pertanian. LP3ES, Jakarta.

Rahim, dan Hastuti. 2007. Pengantar, Teori dan Kasus Ekonomika Pertanian. Penebar Swadaya. Jakarta.

Soekartawi, 2000. Pengantar Agroindustri. Jakarta: PT Raja Grafindo Persada. , 2002. Analisis Usahatani. Universitas Indonesia: Jakarta. 
Sudarmi.2008. Tingkat Optimasi Penggunaan Faktor Produksi Usaha Tempe di Kecamatan Banyudono Kabupaten Boyolali, Skripsi Fakultas Pertanian Universitas Veteran Bangun Nusantara, Sukoharjo

Suratiyah, Ken. 2009. Ilmu Usahatani. Penebar Swadaya : Jakarta. 